\title{
Visitors' Perceptions Of Service Quality In Taman Eden 100 Agro-Tourism
}

\author{
Donny Ivan Samuel Simatupang ${ }^{1 *}$, Helena Tatcher Pakpahan ${ }^{2}$, Desyanti Chrismash ${ }^{3}$ \\ 1,2 Agribusiness Lecturer, Faculty of Agriculture, Indonesian Methodist University \\ ${ }^{3}$ Student of Agribusiness Department, Faculty of Agriculture, Indonesian Methodist University \\ *Correspending Author : \\ Email: donnyivan83@gmail.com
}

\begin{abstract}
This study aims to describe the level of visitor satisfaction in Eden 100 Agrotourism based on visitor perceptions, analyze the service performance of Eden 100 Agrotourism Center to influence service quality at Eden 100 Agrotourism Park, and how to improve service quality in Eden 100 Agrotourism Area. purposive, namely in Eden 100 Agrotourism which is located in Lumbanjulu Village, Lumbanrang District, Toba Samosir Regency, North Sumatra Province. This sampling method uses purposive sampling, the sampling technique is not based on random, regional or start, but based on considerations that focus on certain goals. The data analysis method used is a descriptive method and Importance Performance Analysis. The results of the study where the calculations were carried out using the help of SPSS version 15. The results of this study were: 1) The level of suitability of visitors was $73.05 \%-114.15 \%$, the average level of conformity obtained was $96.53 \%$. The average value of conformity is $17.62 \%$ lower than the level of visitor satisfaction which should be $114.15 \%$. In this case, it can be concluded that the level of service performance of Taman Eden Agrotourism 100 is lower than the level of interest or expectations of visitors. 2) Based on the measurement results using Importance Performance Analysis, it can be seen in the Cartesian diagram that the location of items that affect visitor satisfaction with service quality at Taman Eden Agrotourism 100 is divided into four quadrants. 3). Based on the results of the Cartesian diagram, it is known that the service quality dimension attributes that need special attention are in quadrant $A$ (priority) in the context of agro-tourism efforts in improving service quality, including a. the ability of employees to guide visitors which is included in the reliability variable, $b$. employees are willing to provide fast service which is included in the responsiveness variable, $c$. the patience of employees in providing services that are included in the guarantee variable, $d$. employees do not discriminate in serving visitors which are included in the guarantee variable.
\end{abstract}

Keywords: Visitor Perception, Service Quality, Satisfaction Level, Performance.

\section{INTRODUCTION}

The tourism sector is one of the important sectors that contribute to Indonesia's state income. In 2016 the tourism sector contributed US\$ 11.206 billion in foreign exchange, US\$13.139 billion in 2017, and US\$16,426 billion in 2018. (BPS, 2018). The abundance of Indonesia's natural resources can be used as a tourism sector, especially agro-tourism. Agrotourism is a translation from English, Agrotourism (Widiyanto, 2015). Agro means agriculture and tourism means tourism. Agrotourism is a trip to an area whose target is agriculture (fishing, plantation, forestry, and so on). The growth of tourism in Indonesia is growing rapidly as evidenced by the increasing number of foreign tourists visiting Indonesia every year. The number of foreign tourist visits during 2018 reached 15.81 million visits, an increase of 12.58 percent compared to the number of foreign tourists visiting the same period in 2017 which amounted to 14.04 million visits (BPS, 2018). In 2019, the number of foreign tourist visits to Indonesia reached 16.11 million visits, an increase of 1.88 percent compared to the number of foreign tourists visiting the same period in 2018 of 15.81 million visits (BPS, 2019). North Sumatra Province has enormous potential, natural tourism with natural beauty that makes people intend to visit this province. Tourism objects in North Sumatra can be developed, managed, and promoted and are able to attract tourists to visit both domestic and foreign tourists. The number of competitors in the same business, then 
consumers will have many choices in consuming a product so that business people need to have a competitive advantage.

Companies are required to always provide the best service to their customers, especially for companies engaged in services. One of the main factors for companies engaged in these services is the services provided to consumers to achieve customer satisfaction. One way that can be done to create customer satisfaction is to improve the quality of service. The following data on the number of tourist visits in 8 districts in the Lake Toba area can be seen in Table 1 below:

Table 1. Data on the Number of Tourists Visiting 8 Regencies in the Lake Toba Region:

\begin{tabular}{ccccc}
\hline No & district & \multicolumn{3}{c}{ Number of Tourists } \\
& & Domestic & Foreign & Total \\
\hline 1. & Tapanuli Utara & 108.117 & 1.665 & 109.782 \\
2. & Toba Samosir & 209.180 & 20.108 & 229.288 \\
3. & Dairi & 261.736 & 0 & 261.736 \\
4. & Karo & 552.430 & 2.453 & 554.883 \\
5. & Humbang Hasudutan & 245.482 & 16.254 & 261.736 \\
6. & Pakpak Barat & 27.082 & 0 & 27.082 \\
7. & Simalungun & 189.522 & 21.971 & 211.497 \\
8. & Samosir & 315.925 & 65.724 & 381.649 \\
\hline
\end{tabular}

source : Badan Pusat Statisk Provinsi Sumatera Utara dalam angka tahun 2020.

The Eden Hundred Gardens tourist location has quite attractive tourism potential for tourists and is famous for its natural beauty, tree planting, toba orchids, tarzan houses and unique waterfalls. Some of these potential attractions are unspoiled natural scenery with a cool environment and there are still green trees (forests) around it, besides the natural scenery is very interesting to see from a distance, the very beautiful water of Lake Toba attracts the attention of tourists. visitors. Every visitor who comes to a recreation area has a perception of the surrounding stimuli. Perception consists of visual perception, auditive perception, tactile perception, and kinesthetic perception, according to the opinion (Slameto, 2011) "Perception is a process that involves the entry of messages or information into the human brain." This study aims to (1) determine the level of importance to the performance of Agrotourism Eden 100 (2) determine the performance of services Agrotourism Eden 100 to influence the quality of service at the Garden of Agro Eden 100. (

\section{METHODS}

\section{Method of Determination of Research Area}

The method of determining the research area is carried out purposively or intentionally in Eden 100 Agrotourism which is located in Lumbanjulu Village, Lumbanrang District, Toba Regency, North Sumatra Province because Eden 100 Agrotourism is located in Toba Regency which is one of the tourism development districts in the North. Sumatra Province.

\section{Sampling Method}

Sampling using the Purposive Sampling method. The purposive sampling method is a sampling technique that is not based on random, regional, or strata but based on considerations that focus on certain goals. The total population in this study was 30 respondents consisting of visitors, owners, and local governments.

\section{Method of collecting data}

The data used in this study are primary data and secondary data. Primary data were obtained from direct interviews with tourists, owners, and the government. The questionnaire posed to the respondents was in the form of a list of closed questions. The list of closed questions contains questions whose answers have been provided using a score of 1 (strongly disagree) to 5 (strongly agree). 


\section{Data analysis method}

To answer the formulation of problems 1, 2, and 3 using Importance Performance Analysis. This technique is used to determine the level of customer satisfaction with service quality. In this study there are two variables used, namely:

1. Variable X. namely the performance of Eden Garden 100 Agrotourism in providing services to visitors.

2. Variable Y, namely visitor satisfaction with the quality of services for Agrotourism Taman Eden 100.

To find out the level of suitability of respondents using the formula

\section{Tki= $\underline{\text { Xi }} \times 100$}

\section{Yi}

Dimana:

Tki $=$ respondent's level of conformity

$\mathrm{Xi}$ = company performance appraisal score

$\mathrm{Yi}=$ corporate interest assessment score

If the level of conformity obtained is greater, it indicates that the level of customer interest can be met by the company or the level of company performance is following customer expectations and vice versa.Importance Performance Analysis (IPA) is a descriptive statistical method. The interesting thing about science is that research results are presented in a 2-dimensional quadrant that is graphic and easy to interpret. The results of the quadrant research exemplified by Martilla and James are as follows:

\begin{tabular}{|c|c|}
\hline A & B \\
Concentrate Here & $\begin{array}{c}\text { Keep Up The } \\
\text { Good Work }\end{array}$ \\
\hline C & $\begin{array}{c}\text { D } \\
\text { Possible Overkill }\end{array}$ \\
\hline
\end{tabular}

Fig 1. Kuadran Importance Performance Analysis

In Interpreting The Quadrants, Both Specify As Follows:

\section{A. Concentrate Here}

The factors located in this quadrant are considered as important factors and/or expected by consumers but the current condition of perception and or actual performance is not satisfactory so that the management is obliged to allocate adequate resources to improve the performance of these various factors. Factors in this quadrant are priorities to be improved.

\section{B. Keep up with the good work}

Factors located in this quadrant are considered important and are expected to be supportive factors for customer satisfaction so that the management is obliged to ensure that the performance of the institution it manages can continue to maintain the achievements that have been achieved.

\section{Low Priority (low priority)}

Factors located in this quadrant have a low level of perception or actual performance at the same time are considered not too important and or not too expected by consumers so that management does not need to prioritize or pay too much attention to these factors.

\section{Possibly Overkill (too much)}

Factors located in this quadrant are considered not too important and or not too expected so that management needs to allocate resources related to these factors to other factors that have a higher priority for handling which still need improvement, such as in quadrant B. 


\section{RESEARCH RESULT}

\section{Level of Interest of Visitors to Agro-tourism Performances}

Analyzing the level of visitor interest in agro-tourism performance, it can be seen the order of priority of service quality items that need to be improved. Service quality items will be sorted based on the level of conformity with the lowest to the highest percentage to make it easier for Agrowisata Taman Eden 100 to find out which items need the most improvement efforts. The priority order of service quality items can be seen in Table 2 below:

\begin{tabular}{|c|c|c|c|c|}
\hline No & Item & $\begin{array}{c}\text { Performan } \\
\text { ce Level } \\
\text { (X) }\end{array}$ & $\begin{array}{c}\text { Level of } \\
\text { Interest (Y) }\end{array}$ & $\begin{array}{l}\text { Conformi } \\
\text { ty Level }\end{array}$ \\
\hline 18 & $\begin{array}{l}\text { Employees have knowledge and skills in carrying } \\
\text { out their duties }\end{array}$ & 122 & 167 & 73,05 \\
\hline 10 & $\begin{array}{l}\text { The ability of employees to maintain the comfort } \\
\text { and safety of visitors. }\end{array}$ & 122 & 136 & 89,70 \\
\hline 8 & The ability of employees to guide visitors. & 119 & 131 & 90,83 \\
\hline 3 & Agrotourism appearance & 122 & 133 & 91,72 \\
\hline 24 & Employees do not discriminate in serving visitors & 125 & 134 & 93,28 \\
\hline 2 & Cleanliness of physical facilities & 129 & 138 & 93,47 \\
\hline 4 & Neat appearance of employees & 122 & 130 & 93,84 \\
\hline 1 & Availability of adequate physical facilities & 134 & 142 & 94,36 \\
\hline 12 & Employees are willing to provide fast service & 116 & 122 & 95,08 \\
\hline 9 & $\begin{array}{l}\text { The ability of employees to meet the needs of } \\
\text { visitors }\end{array}$ & 120 & 126 & 95,23 \\
\hline 5 & Affordable ticket prices & 124 & 130 & 95,38 \\
\hline 16 & The patience of employees in providing services. & 121 & 126 & 96,03 \\
\hline 14 & Employees use easy-to-understand language & 133 & 137 & 97,08 \\
\hline 13 & Employees respond to visitors immediately & 120 & 123 & 97,56 \\
\hline 19 & $\begin{array}{l}\text { One hundred Eden Gardens always maintain } \\
\text { security and safety in Agrotourism }\end{array}$ & 131 & 134 & 97,76 \\
\hline 6 & Conformity of service implementation with plan & 115 & 117 & 98,29 \\
\hline 22 & Employees' patience in providing services & 120 & 122 & 98,36 \\
\hline 15 & $\begin{array}{l}\text { Employees have the ability to provide maximum } \\
\text { service }\end{array}$ & 122 & 124 & 98,38 \\
\hline 23 & Employees serve visitors sympathetically & 124 & 126 & 98,41 \\
\hline 21 & Employees give individual attention & 107 & 108 & 99,07 \\
\hline 17 & $\begin{array}{l}\text { Employees provide a sense of security to visitors } \\
\text { when visiting agro-tourism }\end{array}$ & 126 & 123 & 102,43 \\
\hline 20 & Employees have good technical skills & 124 & 121 & 102,47 \\
\hline 7 & Employee concern for visitors & 126 & 122 & 103,27 \\
\hline 25 & Employees handle visitor complaints well & 127 & 122 & 104,09 \\
\hline 11 & Employees provide clear information to visitors & 121 & 106 & 114,15 \\
\hline
\end{tabular}

Based on Table 2 above, it can be seen that the level of suitability of visitors is $73.05 \%-114.15 \%$, this shows that Eden Garden 100 Agrotourism can meet visitors' expectations of the quality of services provided. The average level of conformity obtained is $96.53 \%$. This level of conformity aims to describe the position of items in the process of implementing improvements that will be carried out by Agrotourism Eden 100, from the table can also be seen the order of priority items that need to be improved by agro-tourism. -tourism managers in providing services for Agrotourism of Eden Gardens 100. The table shows the order of priority of the highest item with the lowest level of suitability, namely item 18 (employees have knowledge and skills in carrying out their duties) with a percentage of $73.05 \%$ which has a performance level value of 122 and a level of the performance level of 122. of interest 167, it can be seen the difference between the level of performance and the level of importance of 45 , where the difference in the highest value is between the difference in the level of performance and the level of importance of other items. 
This shows that agro-tourism managers are less able to meet visitor expectations regarding employee knowledge and skills. Visitors to Tamam Eden 100 Agrotourism expect and want employees in agro-tourism to have better knowledge and skills. The item with the lowest priority order but has the highest level of conformity is item 11 (employees provide clear information to visitors) with a percentage of $114.15 \%$ which has a performance level value of 121 and an importance level is 106, the difference in value between the level of performance and the level of importance is 15 . Where the difference is the lowest value between the difference in the level of performance and the level of importance of other items. Employees are good at providing clear information to visitors, so their expectations for guaranteed clear information are high.The determination of which items need to get the attention of agro-tourism managers in providing services at Taman Eden Agrotourism 100 can be seen in the description of these items on the Cartesian diagram so that the steps for improving agro-tourism performance are focused on items that are considered important by consumers.

\section{Agrotourism Performance Affects Visitor Satisfaction}

To analyze the performance of agro-tourism in influencing visitor satisfaction, it can be seen in the description of the items on the Cartesian diagram, to get the position of each item on the Cartesian diagram by calculating the average value of the average level of importance assessment and performance level assessment. These two values are objective limits in the mapping of each item in the Cartesian diagram. The results of these calculations can be seen in Table 3 below:

\begin{tabular}{|c|c|c|c|}
\hline No & Item & $\begin{array}{c}\text { Performance } \\
\text { Level (X) }\end{array}$ & $\begin{array}{c}\text { Level of } \\
\text { Interest (Y) }\end{array}$ \\
\hline 1 & Availability of adequate physical facilities & 4,46 & 4,73 \\
\hline 2 & Cleanliness of physical facilities & 4,3 & 4,6 \\
\hline 3 & Agrotourism Appearance & 4,6 & 4,43 \\
\hline 4 & Neat appearance of employees & 4,13 & 4,33 \\
\hline 5 & Affordable ticket prices & 4,3 & 4,33 \\
\hline 6 & Conformity of service implementation with plan & 3,83 & 3,9 \\
\hline 7 & Employee concern for visitors & 4,2 & 4,6 \\
\hline 8 & The ability of employees to guide visitors. & 3,96 & 4,36 \\
\hline 9 & The ability of employees to meet the needs of visitors & 4 & 4,2 \\
\hline 10 & $\begin{array}{l}\text { The ability of employees to maintain the comfort and } \\
\text { safety of visitors }\end{array}$ & 4,6 & 4,53 \\
\hline 11 & Employees provide clear information to visitors & 4,3 & 3,53 \\
\hline 12 & Employees are willing to provide fast service & 3,86 & 4,6 \\
\hline 13 & Employees respond immediately to visitors & 4 & 4,1 \\
\hline 14 & Employees use easy-to-understand language & 4,43 & 4,56 \\
\hline 15 & Employees can provide maximum service & 4,6 & 4,13 \\
\hline 16 & The patience of employees in providing services. & 4,3 & 4,2 \\
\hline 17 & $\begin{array}{l}\text { Employees provide a sense of security to visitors when } \\
\text { visiting agro-tourism }\end{array}$ & 4,2 & 4,1 \\
\hline 18 & $\begin{array}{l}\text { Employees have knowledge and skills in carrying out their } \\
\text { duties }\end{array}$ & 4,6 & 5,56 \\
\hline 19 & $\begin{array}{l}\text { Hundred Gardens of Eden always maintain security and } \\
\text { safety in Agrotourism }\end{array}$ & 4,36 & 4,46 \\
\hline 20 & Employees have good technical skills & 4,13 & 4,3 \\
\hline 21 & Employees give individual attention & 3,56 & 3,6 \\
\hline 22 & Employees' patience in providing services & 4 & 4,6 \\
\hline 23 & Employees serve visitors sympathetically & 4,13 & 4,2 \\
\hline 24 & Employees do not discriminate in serving visitors & 4,16 & 4,46 \\
\hline \multirow[t]{2}{*}{25} & Employees handle visitor complaints well & 4,23 & 4,6 \\
\hline & Average $\mathrm{X}$ and Y Nilai Values & 4,2096 & 4,3604 \\
\hline
\end{tabular}


Based on Table 3 above, it is known that the value of $\mathrm{X}$ (the average value of the average level of performance) is 4.2096 and the value of $\mathrm{Y}$ (the average value of the level of importance) is 4.3604. These values of $\mathrm{X}$ and $\mathrm{Y}$ will divide the Cartesian diagram into four parts. The position of each item will appear on the Cartesian diagram in the form of ordinate points ( $\mathrm{X}$ and $\mathrm{Y}$ ) as shown below:

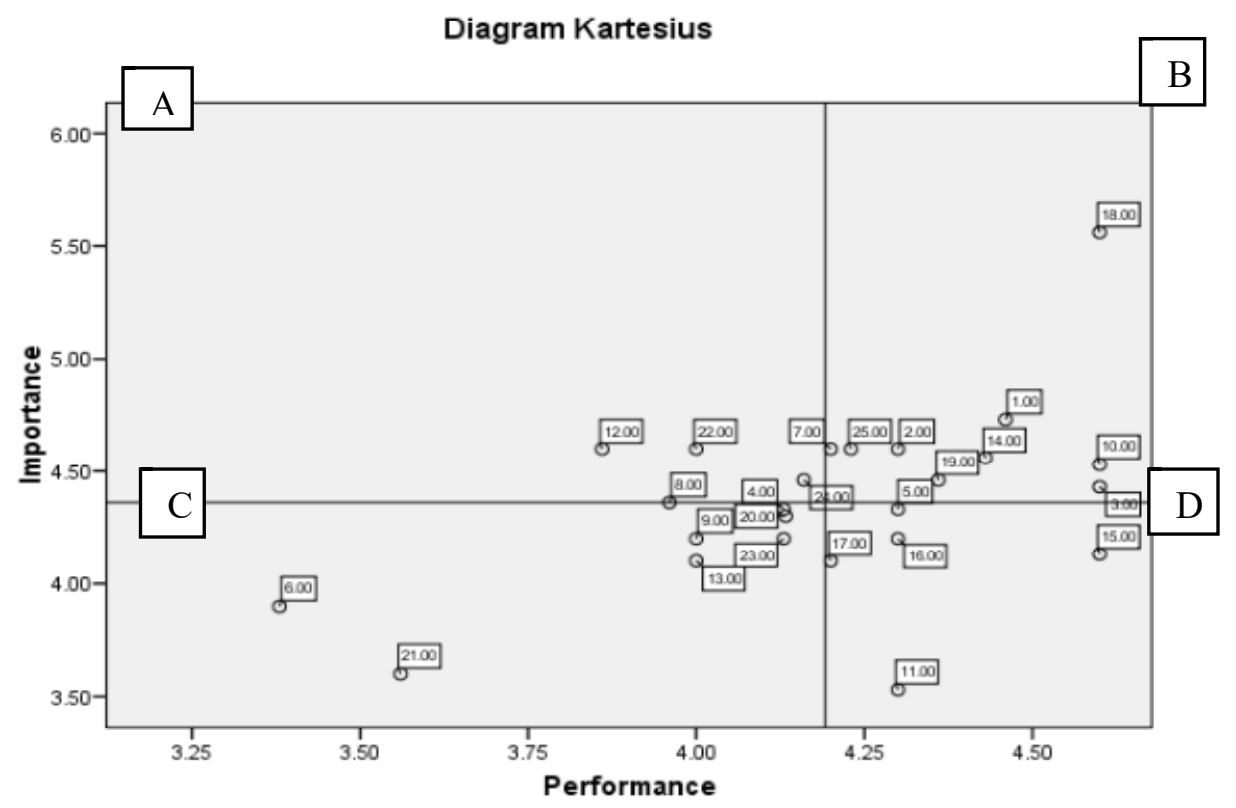

The results of the measurement of the items above are based on the level of importance and level of performance that allows agro-tourism to focus on efforts to improve items that are considered important by visitors to create visitor satisfaction.In the Cartesian diagram above, it can be seen that the locations of items that affect visitor satisfaction with service quality at Taman Eden Agrotourism 100 are divided into four quadrants. The interpretation of the Cartesian diagram above is as follows:

\section{Quadrant $A$}

Shows the items that affect visitor satisfaction that need to be prioritized by the agro-tourism side, because the existence of these items is considered very important by visitors, but the Agro-tourism Garden of Eden 100 has not implemented it according to the level of interest of visitors so that the level of satisfaction obtained by visitors is not maximized. The items included in this quadrant must be improved and placed as a top priority in efforts to improve service quality. These items have an average performance below the objective limit of 4.2096, while the average importance rating is above the objective limit of 4.3604. In general, the items in this quadrant perform well. 3 items are included in quadrant A, namely:

a. Item 8 (the ability of employees to guide visitors) with an average performance rating of 3.96 and an average rating of 4.36 .

b. Item 12 (employees willing to provide prompt service) with an average performance rating of 3.86 and an average rating of 4.6 .

c. Item 22 (employees' patience in providing services) with an average performance rating of 4 and an average rating of 4.6 .

d. Item 24 (employees do not differentiate in serving visitors) with an average performance rating of 4.16 and an average assessment of 4.46 interests.

The results of the Cartesian diagram can be seen that item 8 (employees' ability to guide visitors) is an item included in the reliability variable, item 12 (employees provide services quickly) is an item included in the 
responsiveness variable, and item 22 (employees' patience in providing services). ), and item 24 (employees do not differentiate in serving visitors) is an item included in the empathy variable.

\section{Quadrant B}

Shows items that affect visitor satisfaction that need to be prioritized by agro-tourism because these items are considered important and have been carried out properly following the wishes of visitors. These items have an average performance above the objective limit of 4.2096, while the average importance rating is above the objective limit of 4.3604. There are 9 items included in quadrant B, namely:

A. Point 1 (availability of adequate physical facilities) with an average performance value of 4.46 and an average value of 4.73 importance.

B. Item 2 (cleanliness of physical facilities) with an average performance score of 4.3 , and an average importance value of 4.6 .

C. Item 3 (agro-tourism performance), with an average performance rating of 4.6 and an average importance rating of 4.43 .

D. Item 7 (employees care for visitors), with an average performance rating of 4.2 and an average rating of 4.6.

e. Item 10 (employees' ability and maintain the comfort and safety of visitors) with an average performance value of 4.6 and an average value of 4.53 interest.

F. Item 14 (employees use easy-to-understand language) with an average score of 4.43 for performance and an average score of 4.56 for importance.

G. Item 18 (employees have skills in carrying out their duties) with an average performance rating of 4.6 and an average importance rating of 4.56 .

H. Item 19 (Eden Garden 100 always maintains security and safety in agro-tourism) with an average performance rating of 4.36 and an average rating of 4.46 interest.

I. Item 25 (Employees handle visitor complaints well) with an average performance score of 4.23 and an average rating of 4.6 .

The results of the Cartesian diagram show that item 1 (availability of adequate physical facilities), item 2 (cleanliness of physical facilities), and item 3 (agrotourism performance) are items that are included in the physical evidence variable. Item 7 (employee's concern for visitors), and item 10 (employee's ability to maintain the comfort and safety of visitors) are items that are included in the reliability variable. Item 14 (employees use language that is easy to understand) is an item included in the responsiveness variable. Item 18 (employees have skills in carrying out their duties), and Item 19 (Eden Garden 100 always maintains security and safety in agrotourism), is an item included in the guarantee variable. Item 25 (Employees handle visitor complaints well), is an item that is included in the empathy variable.

\section{Quadrant $C$}

Shows items that affect visitor satisfaction with low priority to be immediately carried out by the agrotourism party, because even though the performance has not been maximized, visitors also consider it not too important. These items have an average performance below the objective limit of 4.2096, while the average importance rating is below the objective limit of 4.3604. There are 7 items included in quadrant $\mathrm{C}$, namely:

a. Item 4 (neat appearance of employees) with an average performance rating of 4.13 and an average importance rating of 4.33 .

b. Item 6 (conformity of service implementation with the plan) with an average performance rating of 3.83 and an average assessment of the importance of 3.9.

c. Item 9 (employees' ability to meet the needs of visitors) with an average performance rating of 4 and an average rating of 4.2 .

d. Item 13 (employees respond to visitors promptly) with an average performance rating of 4 and an average rating of importance of 4.1 . 
e. Item 20 (Employees have good technical skills) with an average performance rating of 4.13 and an average rating of 4.3 .

f. Item 21 (employees give individual attention) with an average performance rating of 3.56 and an average rating of 3.6.

g. Item 23 (employees serve visitors sympathetically) with an average performance rating of 4.13 and an average rating of 4.2 .

The results of the Cartesian diagram can be seen that Item 4 (neat appearance of employees) is an item that is included in the physical evidence variable. Item 6 (conformity of service implementation with the plan) and Item 9 (employee's ability to meet the needs of visitors) are items that are included in the reliability variable. Item 20 (Employees have good technical skills) is an item that is included in the guarantee variable. Item 21 (employees give individual attention) and Item 23 (employees serve visitors sympathetically) are items that are included in the empathy variable.

\section{Quadrant D}

Showing items that affect visitor satisfaction are excessive because the existence of items that are considered less important by visitors but implementation by agro-tourism is considered excessive. These items have an average performance above the objective limit of 4.2096 while the average importance rating is below the objective limit of 4.3604 . There are 5 that are included in quadrant $\mathrm{D}$, namely:

a. Item 5 (affordable ticket prices) with an average performance rating of 4.3 and an average importance rating of 4.33 .

b. Item 11 (employees provide clear information to visitors) with an average performance rating of 4.3 and an average rating of interest of 4.53 .

c. Item 15 (employees can provide maximum service) with an average performance rating of 4.6 and an average assessment of the importance of 4.13 .

d. Item 16 (employees' patience in providing services) with an average performance rating of 4.3 and an average rating of 4.2 .

e. Item 17 (employees provide a sense of security to visitors when visiting agro-tourism) with an average performance rating of 4.2 and an average rating of 4.1 importance.

The results of the Cartesian diagram can be seen that item 5 (affordable ticket prices) is an item that is included in the physical evidence variable. Item 11 (employees provide clear information to visitors) is an item that is included in the responsiveness variable. Item 15 (employees can provide maximum service), Item 16 (employees' patience in providing services), and Item 17 (employees provide a sense of security to visitors when visiting agro-tourism) are items that are included in the guarantee variable.

\section{CONCLUSIONS}

1. The level of suitability of visitors is $73.05 \%-114.15 \%$, the average level of conformity obtained is $96.53 \%$. The average suitability value is $17.62 \%$ lower than the level of visitor satisfaction which should be $114.15 \%$. In this case, it can be concluded that the level of service performance of Taman Eden Agrotourism 100 is lower than the level of interest or visitors' expectations

2. Based on the measurement results using Importance Performance Analysis, it can be seen in the Cartesian diagram the locations of items that affect visitor satisfaction with service quality at Taman Eden Agrotourism 100 are divided into four quadrants.

3. Based on the results on the Cartesian diagram, it is known that the attributes of the service quality dimension that need special attention are in quadrant A (priority) in the context of agro-tourism efforts in improving service quality, among others:

a. The ability of employees to guide visitors which is included in the reliability variable.

b. Employees are willing to provide fast service which is included in the responsiveness variable. 
c. The patience of employees in providing services is included in the guarantee variable.

d. Employees do not discriminate in serving visitors which are included in the guarantee variable.

\section{REFERENCES}

[1] Kotler, Philip. 2011. Manajemen Pemasaran. Jakarta; Salemba Empat

[2] Lupioyadi, dkk. 2016. Manajemen Pemasaran Jasa. Jakarta; Salemba Empat.

[3] Rambat Lupiyoadi dan Bramulya. 2015. Model Importance Performance Analysis. Jakarta; Salemba Empat.

[4] Rangkuti, Fredy. 2016. Measuring Customer Satification. Jakarta; Gramedia Pustaka Utama.

[5] Schindler \& Cooper. (2011). Purposive Sampling adalah metode pengambilan sampel yang memenuhi kriteria tertentu sebagai anggota sampling.

[6] Slameto. 2011. Belajar dan Faktor-Faktor Yang Mempengaruhinya. Jakarta; Rineka Cipta.

[7] Widiyanto,I. 2015. Anteseden Minat Berkunjung Ulang (Studi Pada Cagar Budaya

[8] Lawang Sewu Semarang. Semarang; Journal Of Management. 